\title{
The effect of oxygen content in soapnut biodiesel-diesel blends on performance of a diesel engine
}

\author{
B. P. Pattanaik ${ }^{1 *}$, J. Jena ${ }^{2}$ and R. D. Misra ${ }^{1}$ \\ ${ }^{1}$ Department of Mechanical Engineering, National Institute of Technology Silchar, \\ Silchar 788010, Assam, India \\ ${ }^{2}$ Department of Mechanical Engineering, Gandhi Institute for Education and \\ Technology, Bhubaneswar, Khurda 752060, Odisha, India \\ Phone: +91 9437169040; +918822365256 \\ *E-mail: bppattanaik1977@gmail.com
}

\begin{abstract}
In this study, 18 soapnut biodiesel-diesel blends along with soapnut oil as an additive in some blends were prepared and used in a diesel engine to investigate the effect of oxygen content in the fuel blends on engine performance and emission characteristics. Considering the large variations in the oxygen content of these fuel blends, the obtained results were demonstrated based on varying fuel oxygen content. Findings showed that the best engine performance was achieved with a fuel oxygen content in the range of $1.8 \%-3.0 \%$, whereas the best engine emissions were obtained with a fuel oxygen content in the range of $0.71 \%-2.37 \%$. Hence, considering both engine performance and emissions, the optimal zone of fuel oxygen content was found to be in the range of $1.80 \%$ $2.37 \%$. Thus, it can be concluded that biodiesel blended fuels having an oxygen content in the aforesaid range can be successfully used in diesel engines with comparable engine performance and emissions to those using diesel fuel. Nevertheless, further research is required to reduce the fuel oxygen content to this optimal range if the blends consist of higher biofuel components. Besides that, the use of suitable additives in the biodiesel blended fuels may be a viable option to achieve the said purpose, which needs further research.
\end{abstract}

Keywords: Soapnut biodiesel; diesel engine; engine performance; $\mathrm{NO}_{\mathrm{x}}$ emissions; fuel oxygen content.

\section{INTRODUCTION}

Over the years, the progress in science and technology has changed the lifestyle of humans, which in turn has considerably raised global energy consumption. The demand for fossil fuels has increased accordingly, resulting in faster depletion of the conventional fossil fuel reserves. Furthermore, increase in greenhouse gas content in the atmosphere due to fossil fuel combustion has raised serious concerns for the entire ecosystem. These factors have led to an innovative worldwide search for alternative fuels from renewable sources like biomass. Alternative fuels should be easily available, economically viable, and environmentally acceptable. Biodiesel is one of the promising alternative fuels for diesel engines, which has gained popularity in the past few decades. It mainly consists of methyl and ethyl esters of fatty acids (triglycerides), primarily derived from edible and non-edible straight vegetable oils (SVOs) and animal fats via base catalysed 
transesterification [1-3]. Biodiesel can be produced from a variety of SVO feedstocks such as jatropha, karanja, rapeseed, soybean, palm, etc. [2-7]. Proper utilization of renewable SVOs as fuel, replacing fossil fuel, contributes to climate, water, and soil protection, helps in reducing greenhouse gas emissions, and provide sustainability, regional development, and improvement in agriculture [2, 8]. In developing countries like India and other South-East Asian countries, biodiesel production is mostly concentrated on non-edible oil sources due to a huge demand for edible vegetable oils used for food purposes. Major non-edible oil sources used for biodiesel production in India are jatropha, karanja, jojoba, castor, cottonseed, kokum, mahua, nahor, neem, ricebran, kusum, simarouba, soapnut, tumba, etc. Among these SVO sources, soapnut is a newly found biofuel source and very few literatures are available on production of biodiesel from it. Soapnut or Sapindus mukorossi Gaerth, a member of the Sapindaceae family, is a deciduous tree widely grown in tropical and sub-tropical climate areas in various parts of the world, including Asia, America, and Europe, at altitudes ranging from 200 to $1500 \mathrm{~m}$ [9]. It is also found in the Himalayan region in northern India. Soapnut trees naturally grow in deep clayey loam soil and flourish in areas with an annual rainfall of 150-200 cm [10]. The soapnut seed contains $23 \%$ oil, which has a high triglycerides percentage of $92 \%$. In addition, the oil content in the kernel of the soapnut seed is approximately $42.7 \mathrm{wt} \%$ [10]. The major fatty acids in soapnut oil are oleic (9Z-octadecenoic, C18:1) and eicosenoic (11Z-eicosenoic, C20:1) acids [8]. The high monounsaturated fatty acids content in soapnut oil is its significant feature in comparison with the common fatty acid profiles of vegetable oils. Corresponding to its fatty acid composition, soapnut oil biodiesel potentially exhibits better oxidation stability [11].

Biodiesel is a renewable, biodegradable, and non-toxic fuel and has comparable fuel properties to diesel. Moreover, biodiesel is more advantageous in comparison to diesel fuel due to its higher flash point, lower volatility, and greater lubricity [2, 12-15]. Besides that, biodiesel has a lower aromatic compound content, contains 10\%-12\% oxygen by weight, and is free of sulphur content. Due to the presence of oxygen, a higher degree of oxidation of incompletely burned hydrocarbons, which are generated during combustion, is achieved $[16,17]$. This leads to lower carbon monoxide (CO), unburned hydrocarbons (HC), and particulate matter (PM) emissions with biodiesel fuel. However, higher oxygen content in biodiesels produces higher nitrogen oxides $\left(\mathrm{NO}_{\mathrm{x}}\right)$ emissions, which is a major concern [18-22]. Biodiesel has a higher bulk modulus, sound velocity, viscosity, and cetane number than diesel fuel. These features lead to an advance in start of fuel injection and a short ignition delay [23, 24]. On the other hand, the major disadvantage of biodiesel is its higher viscosity [7, 25-29]. Higher biodiesel viscosity leads to pumping issues, poor atomization, poor cold-flow properties, coking of injectors, plugging of filters, increased carbon deposits on piston head, etc. [2, 23]. Furthermore, other disadvantages of using biodiesel are its lower volatility, heating value, energy density, rate of heat release, and rate of pressure rise, engine power losses, longer combustion duration, and higher brake specific fuel consumption (BSFC). Chauhan et al. [30] observed lower brake thermal efficiency (BTE) and higher BSFC along with lower $\mathrm{HC}, \mathrm{CO}, \mathrm{CO}_{2}$, and smoke emissions, and higher $\mathrm{NO}_{\mathrm{x}}$ emissions for jatropha biodiesel blends compared to diesel fuel. Other than that, Altaie et al. [31] reported that enriched biodiesel blended fuel shows lower brake torque and higher BSFC than diesel fuel due to lower calorific values. Engine emissions such as $\mathrm{CO}, \mathrm{HC}$, and $\mathrm{NO}_{\mathrm{x}}$ were higher due to poor ignition quality. Alptekin [32] showed that use of biodiesel and biodiesel blends in a diesel engine results in higher BSFC, and higher $\mathrm{NO}_{\mathrm{x}}$ and $\mathrm{CO}_{2}$ emissions, and lower $\mathrm{CO}$ and $\mathrm{HC}$ emissions compared to diesel. These and many other research works 
involving biodiesel as fuel in compression ignition (CI) engines show that higher $\mathrm{NO}_{\mathrm{x}}$ emissions from biodiesel combustion is the major hindrance for its commercial scale production, which is primarily due to its higher oxygen content. Therefore, there is a need to evaluate the suitable range of oxygen content in biodiesels and biodiesel blended fuels, which will ensure comparable engine performance along with acceptable engine emission parameters.

In the present work, biodiesel was produced from soapnut oil and used as fuel in a $\mathrm{CI}$ engine in blended form with diesel fuel in suitable volumetric proportions. The aim of the present work is to study the influence of oxygen content in the fuel blends on engine performance and emission characteristics to determine the optimal range of oxygen content in biodiesel fuel for achieving the best engine performance and emissions. Additionally, the role of parent vegetable oil as an additive to biodiesel-diesel blends was also studied to reduce the oxygen content in fuel blends to the optimal range.

\section{MATERIALS AND METHODS}

\section{Fuel Sample Preparation}

In the present experimental investigation, soapnut oil (SO) was selected as the biofuel source. SO was chosen due to its availability and cost in this locality, and being nonedible in nature and a newly established biofuel source. Neat SO was used to produce soapnut biodiesel (SB) via base catalysed transesterification. SB was prepared using a 10litre capacity biodiesel reactor (Gobind Machinery Works, New Delhi). For biodiesel preparation, 5 litres of filtered SO was initially fed into the reactor. This was followed by preparation of a reagent mixture consisting of 1 litre (20\% by vol.) methanol and $100 \mathrm{~g}$ of $\mathrm{KOH}$ (base catalyst). The SO in the reactor was initially preheated a little above room temperature followed by feeding of reagent mixture into the reactor. Stirrer speed was maintained at $750 \mathrm{rpm}$ while reaction temperature was sustained at $60^{\circ} \mathrm{C}$. The transesterification reaction was continued for 90 minutes and then the product was allowed to settle down for a period of 6 hours. Glycerol was collected first from the bottom of the reactor followed by raw biodiesel. The raw biodiesel was then washed three times with water with a settling period of three hours after each washing. After the final washing, settling, and moisture removal, approximately 3.5 litres of pure SB was obtained.

The prepared SB was then blended with diesel in predefined volumetric basis percentages of $10 \%, 15 \%, 20 \%, 25 \%, 30 \%$, and $40 \%$ and were named as SB10, SB15, SB20, SB25, SB30, and SB40, respectively, along with SB100 i.e. 100\% biodiesel. Parent vegetable oil known as SVO i.e. SO, was then used as an additive in small volume percentages of $2.5 \%, 5.0 \%$, and $10.0 \%$ to the already prepared biodiesel blends i.e. SB10, SB15, SB20, and SB25 to prepare a few resulting fuel blends, for example: SB10-SO2.5 ( $10.0 \%$ by vol. of SB, $2.5 \%$ by vol. of parent SVO, and the rest diesel), SB10-SO5, SB15SO2.5, SB15-SO5, and so on. In this way, 18 fuel blends were prepared for the present experimental investigation namely: SB10, SB10-SO2.5, SB10-SO5, SB10-SO10, SB15, SB15-SO2.5, SB15-SO5, SB15-SO10, SB20, SB20-SO2.5, SB20-SO5, SB20-SO10, SB25, SB25-SO2.5, SB25-SO5, SB25-SO10, SB30, and SB40. The aforesaid volumetric proportions of $\mathrm{SB}$ and $\mathrm{SO}$ for preparing these biofuel blends were considered based on oxygen content in the final biofuel blends.

Next, the 18 fuel blends underwent fuel characterisation using various standard ASTM methods. From the fuel characterisation results, it is evident that the density, viscosity, cloud point, and pour point of the fuel blends increased with an increase in 
oxygen content. The density and viscosity of all the fuel blends were observed to be in the range of $837-855 \mathrm{~kg} / \mathrm{m}^{3}$ and $3.05-4.16 \mathrm{cSt}$, respectively. Similarly, cloud and pour points were found to be in the range of $7.0^{\circ} \mathrm{C}-12.6^{\circ} \mathrm{C}$ and $3.5^{\circ} \mathrm{C}-4.9^{\circ} \mathrm{C}$, respectively. A gradual decrease in calorific value of the fuel blends was observed with increase in oxygen content. The calorific value was noticed to vary in the range of 40.74-42.50 $\mathrm{MJ} / \mathrm{kg}$. However, critical observations of the results clearly depicted that all the selected fuel blends exhibited comparable physico-chemical properties with diesel. The fuel characterisation tests were followed with evaluation of carbon, hydrogen, and oxygen percentage present in the fuel blends. A CHN-O elemental analyser (Model-Flash 2000) was used for estimating these components for each fuel blend sample. Fuel characterisation results and percentage of oxygen content for each fuel blend obtained from the elemental analysis are tabulated in Tables 1 and 2, respectively.

Table 1. Fuel characterisation results for SB blends.

\begin{tabular}{llllllllll}
\hline Property & SB10 & SB15 & SB20 & SB25 & SB30 & SB40 & SB100 & Diesel & $\begin{array}{l}\text { ASTM } \\
\text { test no. }\end{array}$ \\
\hline $\begin{array}{l}\text { Density }\left(\mathrm{kg} / \mathrm{m}^{3}\right) \\
\text { Viscosity at } 40^{\circ} \mathrm{C}(\mathrm{cSt})\end{array}$ & 83.05 & 3.10 & 3.17 & 3.35 & 3.61 & 4.11 & 4.86 & 2.83 & $\mathrm{D} 445$ \\
$\begin{array}{l}\text { Calorific value } \\
(\mathrm{MJ} / \mathrm{kg})\end{array}$ & 42.50 & 42.46 & 42.38 & 42.10 & 41.74 & 40.89 & 38.24 & 44.62 & $\mathrm{D} 240$ \\
Flash point $\left({ }^{\circ} \mathrm{C}\right)$ & 91 & 96 & 105 & 108 & 120 & 124 & 175 & 70 & $\mathrm{D} 93$ \\
Cloud point $\left({ }^{\circ} \mathrm{C}\right)$ & 7.00 & 7.50 & 8.40 & 9.20 & 10.70 & 11.50 & 13.50 & 6.40 & $\mathrm{D} 2500$ \\
Pour point $\left({ }^{\circ} \mathrm{C}\right)$ & 3.50 & 3.70 & 4.00 & 4.20 & 4.40 & 4.70 & 5.10 & 3.00 & D97 \\
Cetane index & 48.38 & 48.45 & 48.57 & 48.66 & 48.81 & 48.95 & 51.40 & 48.00 & D613 \\
\hline
\end{tabular}

Table 2. Percentage of oxygen content in SB blends.

\begin{tabular}{llllll}
\hline \multirow{2}{*}{ Fuel blend no. } & \multirow{2}{*}{ Fuel blend name } & \multicolumn{3}{c}{ \% by volume } & \multicolumn{2}{c}{ Oxygen } \\
\cline { 3 - 5 } & & SB & Diesel & SO & (\% by wt.) \\
\hline 1 & SB10 & 10 & 90.0 & 0 & 0.961 \\
2 & SB10-SO2.5 & 10 & 87.5 & 2.5 & 1.210 \\
3 & SB15 & 15 & 85.0 & 0 & 1.240 \\
4 & SB15-SO2.5 & 15 & 82.5 & 2.5 & 1.469 \\
5 & SB10-SO5 & 10 & 85.0 & 5.0 & 1.499 \\
6 & SB20 & 20 & 80.0 & 0 & 1.686 \\
7 & SB15-SO5 & 15 & 80.0 & 5.0 & 1.748 \\
8 & SB10-SO10 & 10 & 80.0 & 10.0 & 1.809 \\
9 & SB25 & 25 & 75.0 & 0 & 2.010 \\
10 & SB20-SO2.5 & 20 & 77.5 & 2.5 & 2.060 \\
11 & SB15-SO10 & 15 & 75.0 & 10.0 & 2.309 \\
12 & SB25-SO2.5 & 25 & 72.5 & 2.5 & 2.329 \\
13 & SB20-SO5 & 20 & 75.0 & 5.0 & 2.377 \\
14 & SB30 & 30 & 70.0 & 0 & 2.410 \\
15 & SB20-SO10 & 20 & 70.0 & 10.0 & 2.648 \\
16 & SB25-SO5 & 25 & 70.0 & 5.0 & 2.830 \\
17 & SB40 & 40 & 60.0 & 0 & 3.070 \\
18 & SB25-SO10 & 25 & 65.0 & 10.0 & 3.602 \\
\hline
\end{tabular}

Fuel blends are reordered according to increasing oxygen content and accordingly their blend number is assigned for future reference (Table 2). From the $\mathrm{CHN}-\mathrm{O}$ analysis, 
it was observed that the variation in oxygen content in all 18 fuel blends is very large i.e. $78.23 \%$. Therefore, it is relevant to use the variations in oxygen percentage as the basis for comparative assessment of the effect of SB blends on performance of the engine.

\section{Experimental Setup}

In the present work, a single-cylinder four-stroke water cooled diesel engine was used for evaluating performance and emission characteristics of the 18 fuel blends along with diesel. The test engine was coupled with an eddy current dynamometer and loading was controlled by a load console. Two separate fuel tanks were used along with a two-way fuel supply line for supplying SB blends and diesel separately to the engine. A five gas analyser (AVL Digas 444) and a AVL 437 smoke meter were connected to the test engine for measuring the engine's emissions. The entire engine test was operated by Enginesoft LV software installed on a computer. A schematic diagram and a photograph of the experimental engine setup are shown in Figures 1 and 2, respectively. Specifications of the test engine are presented in Table 3.

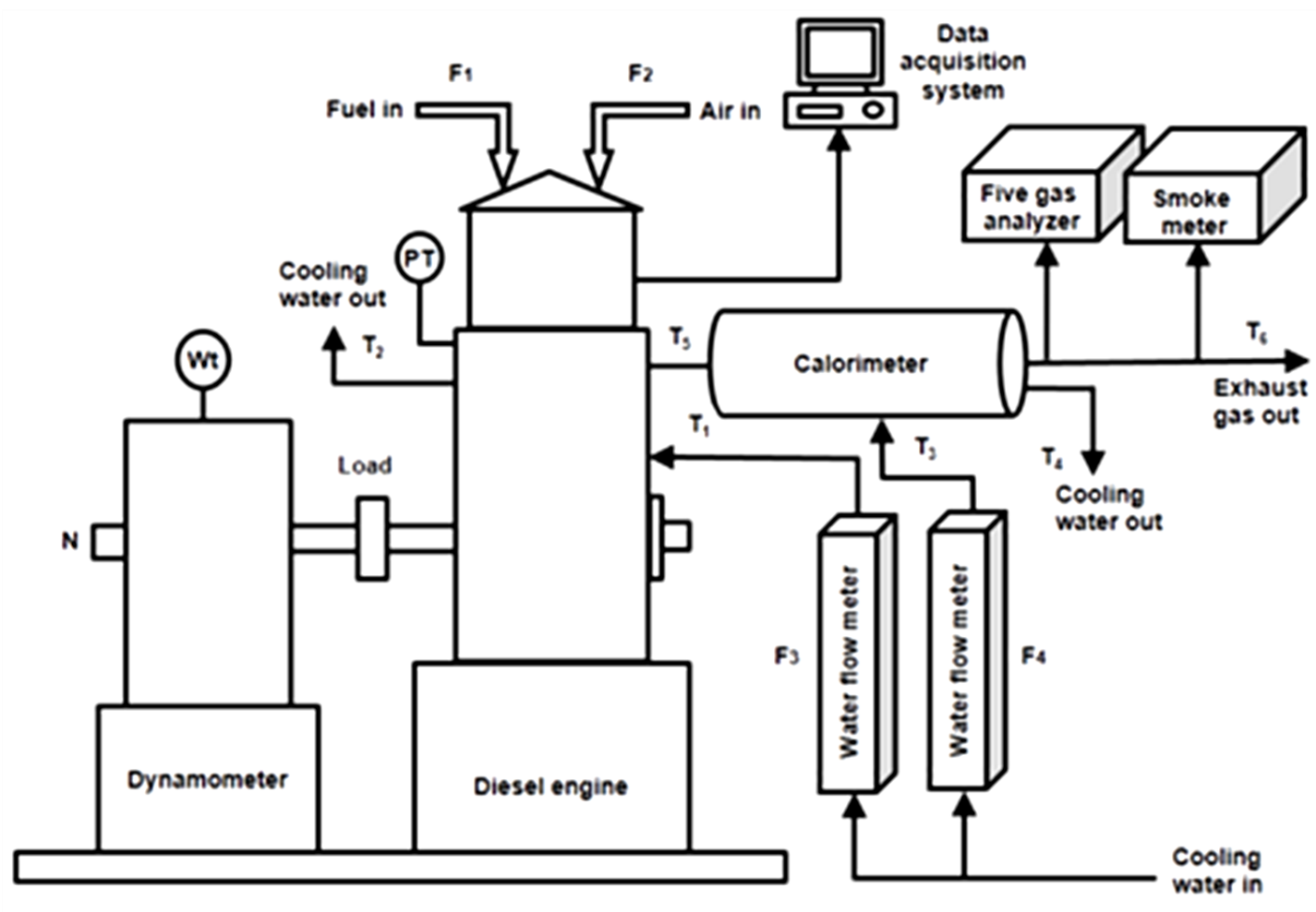

$\mathrm{F}_{1}$ : Fuel injection pressure sensor, $\mathrm{F}_{2}$ : Air flow measuring, $\mathrm{F}_{3}$ : Water flow meter to engine, $\mathrm{F}_{4}$ : Water flow meter to calorimeter, $\mathrm{T}_{1}$ : Cooling water inlet temperature to engine, $\mathrm{T}_{2}$ : Cooling water outlet temperature from engine, $\mathrm{T}_{3}$ : Cooling water inlet temperature to calorimeter, $\mathrm{T}_{4}$ : Cooling water outlet temperature from calorimeter, $\mathrm{T}_{5}$ : Exhaust gas inlet temperature to calorimeter, $\mathrm{T}_{6}$ : Exhaust gas outlet temperature from calorimeter, PT: Piezo sensor, N: rpm pick up and TDC encoder.

Figure 1. Schematic diagram of the experimental engine setup. 


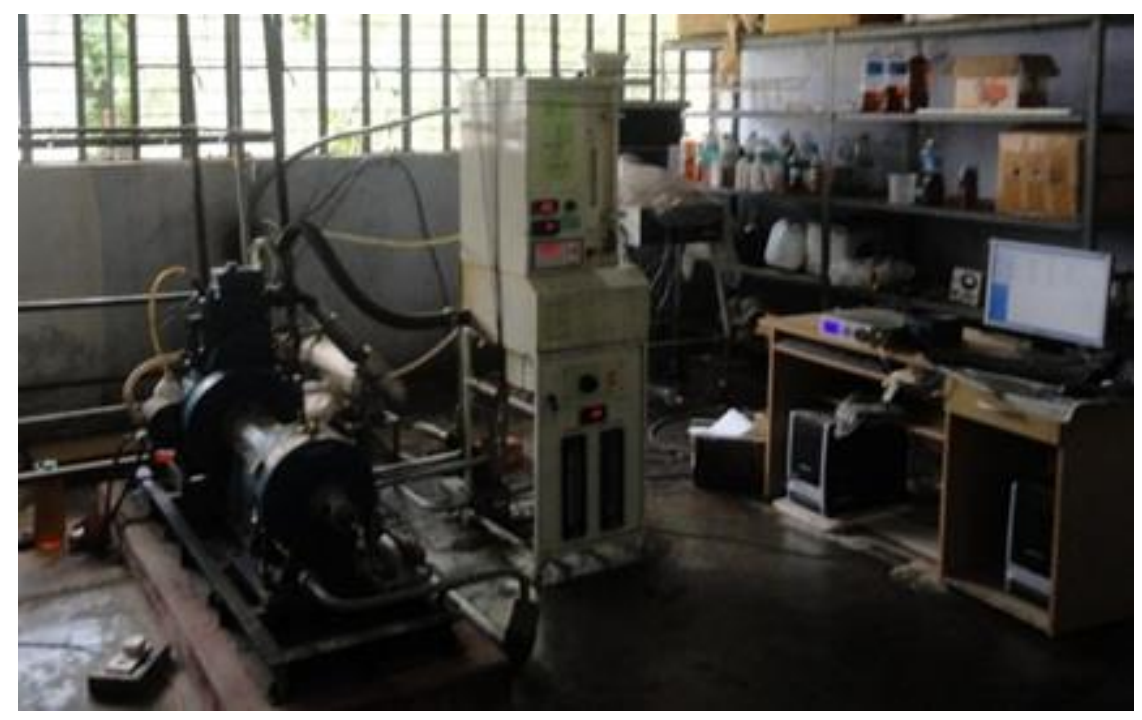

Figure 2. Photograph of the experimental engine setup.

Table 3. Specifications of the test engine.

\begin{tabular}{ll}
\hline Variable & Specification \\
\hline Make & Kirloskar, TV1 model \\
Type & 4-stroke, single-cylinder, water cooled, \\
& direct injection, naturally aspirated \\
Dynamometer & Eddy current, water cooled, with loading unit \\
Bore $\times$ Stroke & $87.5 \mathrm{~mm} \times 110.0 \mathrm{~mm}$ \\
Compression ratio & 17.5 \\
Connecting rod length & $234 \mathrm{~mm}$ \\
Displacement & 0.661 litre \\
Rated power & $5.2 \mathrm{~kW}$ \\
Rated speed & $1500 \mathrm{rpm}$ \\
Fuel injection type & Single barrel F.I. pump, inline fuel injector \\
Injection timing & $23^{\circ} \mathrm{BTDC}$ \\
Inj. opening pressure & $20.5 \mathrm{MPa}$ \\
Injector hole dia. & $3 \times 0.288 \mathrm{~mm}$ \\
Orifice dia. & $20 \mathrm{~mm}$ \\
Dynamometer arm length & $185 \mathrm{~mm}$ \\
Rotameters & Engine cooling 40-400 LPH, Calorimeter 25-250 LPH \\
\hline
\end{tabular}

\section{RESULTS AND DISCUSSION}

From the results, it was observed that there is a wide variation in the range of values for different performance and emission parameters, although qualitatively similar, against varying percentages of oxygen in the fuel blends. Thus, it is necessary to bring down these parameters to a common platform for their comparative assessment. It is a normal practice to bring the varying coordinate axes of different parameters to the same coordinate axes by expressing them as a non-dimensionalised parameter. Since diesel was the base fuel for all the fuel blends in the present work, each engine performance and emission parameters for a particular fuel blend was expressed in terms of a non-dimensionalised 
parameter with respect to diesel fuel. This non-dimensionalised parameter is defined as the ratio of the value of a given performance or emission parameter for a fuel blend to that of diesel fuel. That is, the value of $i^{\text {th }}$ parameter of a specific fuel blend can be expressed as:

$$
\left(\beta_{\text {specific biodiesel blend }}\right)_{i}=i_{\text {specific biodiesel blend }} / i_{\text {diesel }}
$$

As shown in Eq. (1), $\beta_{i}$ is expressed as the non-dimensionalised parameter for the $i^{\text {th }}$ parameter of a specific fuel blend, whereas $i$ is the given engine performance or emission parameter.

\section{Effect of Fuel Oxygen Content on Engine Performance Parameters}

The variations of different engine performance parameters like BTE, brake specific energy consumption (BSEC), and exhaust gas temperature (EGT) against varying percentages of oxygen content in the fuel blends, as obtained from experimentations with the considered fuel blends, are presented in Figure 3 along with necessary discussions on the presented results.

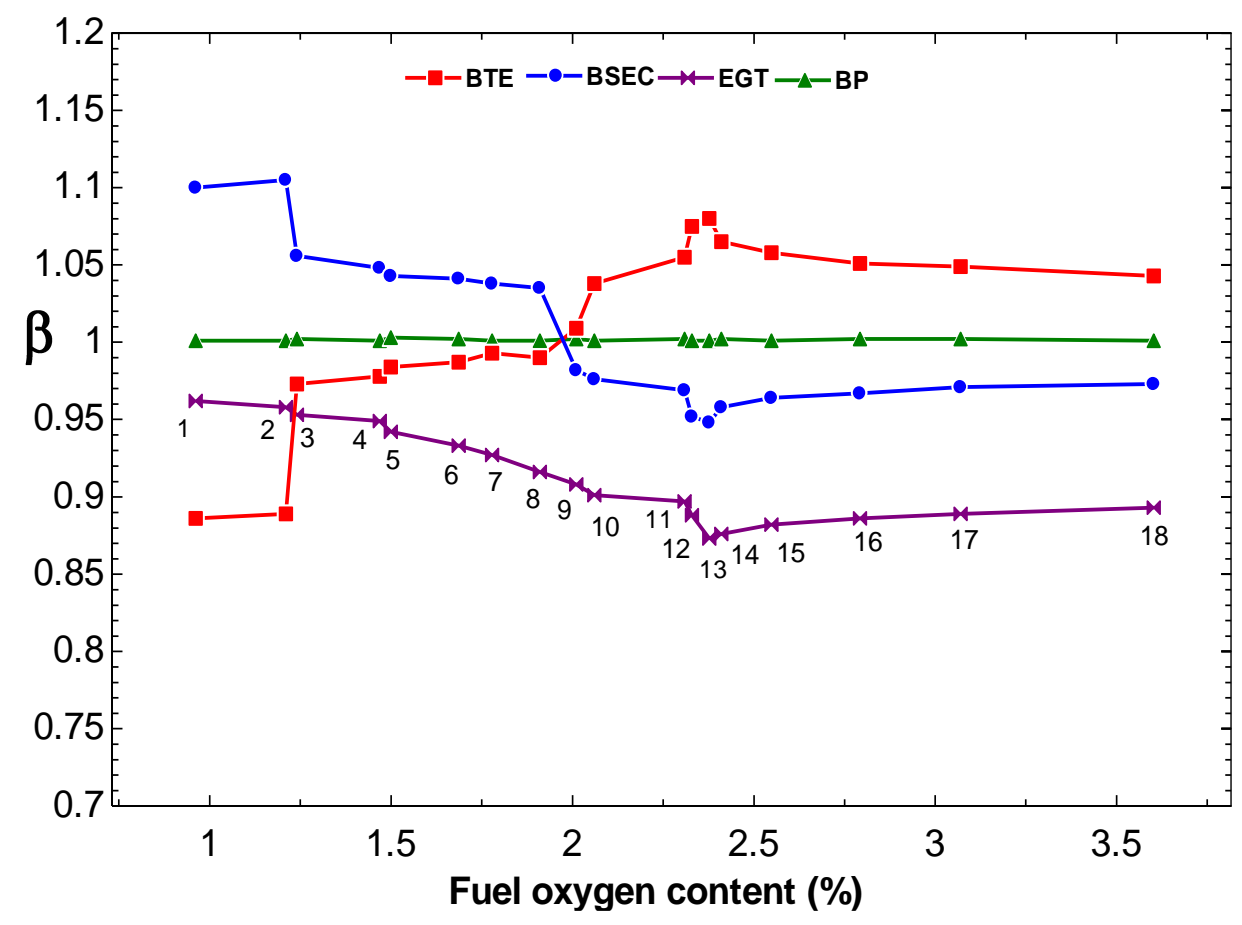

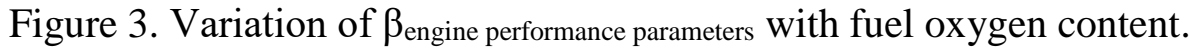

\section{Brake Thermal Efficiency}

BTE is a major engine performance parameter that measures the true power output obtained from the engine shaft. It also specifies the engine's ability to transfer the fuel's chemical energy into mechanical power. It was observed that BTE of the fuel blends overtook that of diesel at about $1.97 \%$ oxygen content in the SB blends. Moreover, it was also observed that $(\beta)_{B T E}$ increased with increase in oxygen percentage up to $2.37 \%$ for the SB fuel blends. Increase in fuel blends' oxygen percentage causes heating value to decrease and less fuel energy is supplied to produce a fixed brake power [33, 34]. Furthermore, it was observed that fuel blends containing more than $1.97 \%$ oxygen 
showed higher BTE than diesel. This may be attributed to the presence of higher oxygen content, which leads to a more complete combustion, thereby resulting in the increase of BTE [33, 35-37]. Secondly, due to higher density of biodiesel blends compared to diesel, a higher mass of fuel is supplied during combustion, which compensates for the decreased heating value of the fuel blends resulting in increased BTE [33, 35].

\section{Brake Specific Energy Consumption}

It was noted that $(\beta)_{B S E C}$ decreased with an increase in oxygen percentage up to $2.37 \%$ for SB blends. Fuel blends with an oxygen percentage of more than $1.97 \%$ performed better showing lower BSEC in comparison to diesel. This may be due to presence of more oxygen that leads to complete combustion, thereby resulting in reduced BSEC [33]. In addition, fuel blends with an oxygen percentage of more than $2.37 \%$ showed a slight increase in $(\beta)_{B S E C}$ compared to diesel. This may be attributed to the higher density and viscosity of these blends causing poor atomization and incomplete combustion, that dominated over the gain in heating value due to which the fuel consumption increased slightly [30, 33, 38, 39]. From these results, it may be realized that fuel blends having an oxygen content between $1.975 \%-2.370 \%$ showed lower BSEC than diesel.

\section{Exhaust Gas Temperature}

With an increase in oxygen percentage up to $2.37 \%$ for SB blends, it was observed that $(\beta)_{E G T}$ decreased. The reason could be that the stoichiometric fuel-air ratio increased with the increase in oxygen percentage in fuel blends, which caused the mixture to reach faster the stoichiometric conditions [40]. Nonetheless, beyond the oxygen percentage of $2.37 \%,(\beta)_{E G T}$ increased, which may be caused by improved combustion due to presence of more oxygen in the fuel blends [41, 42]. Moreover, the most preferable fuel blend was fuel blend number 13, which showed the lowest $(\beta)_{E G T}$ amongst corresponding fuel blends. Thus, after considering all the engine performance parameters, the best engine performance was noted for oxygen content between 1.8\%-3.0\%, irrespective of fuel type, wherein the BSEC for fuel blends was in the minimum range while BTE was in the maximum range.

\section{Effect of Fuel Oxygen Content on Engine Emission Parameters}

Exhaust emissions viz. $\mathrm{CO}, \mathrm{HC}, \mathrm{NO}_{\mathrm{x}}$, smoke opacity, etc. are the primary issues affecting the successful performance of CI engines. Literature shows that biodiesels produce significantly lower $\mathrm{HC}$ and $\mathrm{CO}$ emissions compared to diesel $[30,43,44]$. However, $\mathrm{NO}_{\mathrm{x}}$ emission increases slightly with biodiesel in comparison with diesel. Additionally, parent vegetable oil used as an additive in biodiesel blends may be one of the possible options to reduce $\mathrm{NO}_{\mathrm{x}}$ emissions [45]. Non-dimensionalised emission parameters $(\beta)_{C O},(\beta)_{H C}$, $(\beta)_{\mathrm{CO}_{2}},(\beta)_{N O_{X}}$, and $(\beta)_{P M}$ for SB blends with respect to increase in oxygen content are shown in Figure 4, which is followed by a detailed explanation of results.

\section{CO emissions}

It was observed that with an increase in oxygen percentage in the fuel blends, the $\mathrm{CO}$ emissions reduced gradually. This may be due to the lower carbon content of biodiesel blends compared to diesel $[46,47]$. Thus, with less carbon in the fuel, there is a better chance that each carbon atom will find two oxygen atoms to bind to form $\mathrm{CO}_{2}$. This result agrees with those of Azad et al. [48], who used several soybean and waste cooking oil biodiesel blends and reported lower $\mathrm{CO}$ emissions in all cases compared to diesel. Another possible reason for lower $\mathrm{CO}$ emissions could be that during combustion there 
may be lower possibility of formation of rich fuel zone with the biodiesel fuel blends due to presence of fuel oxygen, and hence $\mathrm{CO}$ emissions got reduced [46]. Furthermore, it is noted that for fuel blends containing more than $2.37 \%$ oxygen content, there was a sharp reduction in $\mathrm{CO}$ emission compared to diesel.

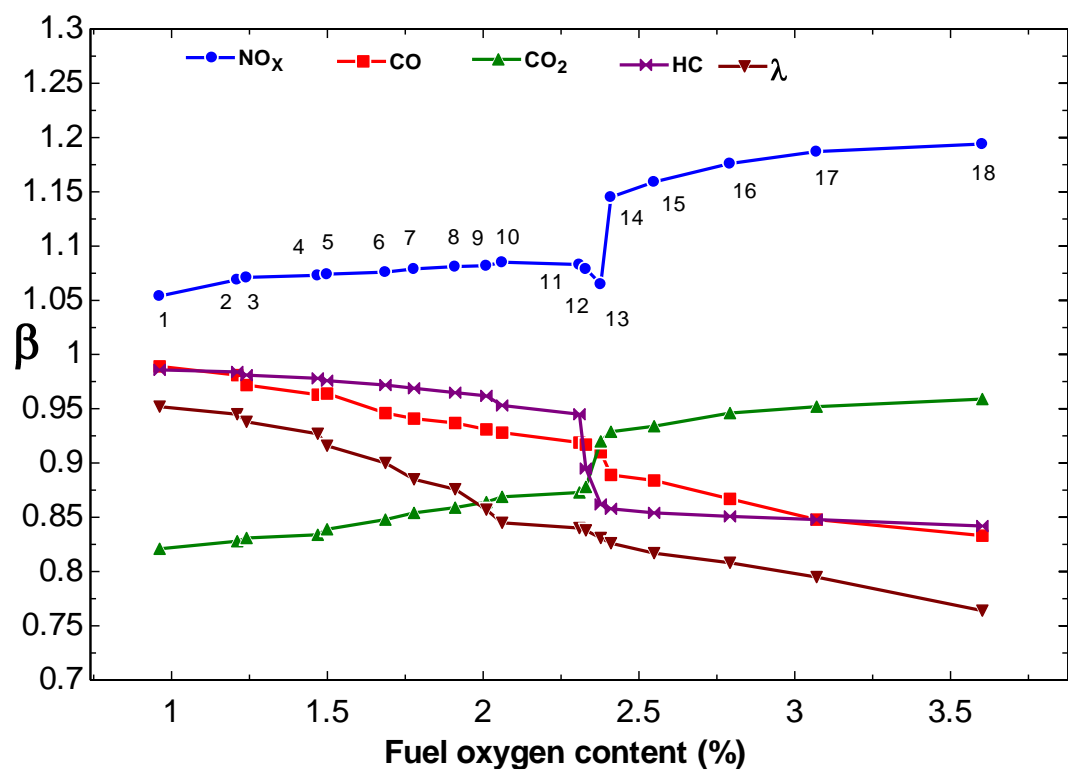

Figure 4. Variation of exhaust emission parameters with fuel oxygen content.

\section{$\mathrm{CO}_{2}$ Emissions}

Figure 4 shows that $\mathrm{CO}_{2}$ emissions increased with increase in oxygen percentage in SB blends. The $\mathrm{CO}_{2}$ emissions for all fuel blends were less than that of diesel. This concurs with results obtained by Dubey and Gupta [49]. This is attributed to the fact that biodiesels are low carbon fuels and have a lower elemental carbon to hydrogen ratio than diesel [47, 50]. Fuel blends having an oxygen content of less than $2.32 \%$ showed comparatively lower $\mathrm{CO}_{2}$ emissions. Nevertheless, beyond these oxygen percentages, all the fuel blends showed a quick rise in $\mathrm{CO}_{2}$ emissions, which may be attributed to higher oxygen percentage in the fuel blends [51].

\section{HC Emissions}

Studies on CI engines proved that engines running with biodiesel fuel blends resulted in lower HC emissions in comparison to diesel [52]. From Figure 4, it is observed that HC emissions reduced with increase in oxygen percentage in the fuel blends. HC emissions for all fuel blends were less than diesel, because the major source of $\mathrm{HC}$ emission is overmixing. Over-mixing is strongly linked with ignition delay as well as with mixing of air and fuel during combustion period [53-55]. Both shorter ignition delay and better atomization were responsible for complete combustion and reduced $\mathrm{HC}$ emissions. It was also observed that at oxygen percentages higher than $2.37 \%$ (blend number $13-18$ ), HC emissions were better than those of other fuel blends, with fuel blend number 18 showing the lowest $\mathrm{HC}$ emission.

\section{NO $O_{x}$ Emissions}

From Figure 4, it is observed that $\mathrm{NO}_{\mathrm{x}}$ emissions increased with increase in oxygen percentage for all SB blends and are higher than that of diesel. NOx emissions increased 
further when oxygen content rose higher than $2.37 \%$, i.e. for blend number 13 . The possible reasons for this could be advanced injection timing, higher $\mathrm{CN}$, higher viscosity, presence of oxygen, and shorter ignition delay $[56,57]$. Advancement of injection timing is responsible for advancing the start of combustion. This may produce higher peak temperature inside the cylinder and may increase the rate of $\mathrm{NO}_{\mathrm{x}}$ production $[56,57]$. Besides that, this also results in a longer residence time, allowing $\mathrm{NO}_{\mathrm{x}}$ production to continue. Furthermore, higher $\mathrm{CN}$ of biodiesel fuel blends shorten ignition delay and thus the start of combustion advances. This results in a significantly longer residence time of higher temperature in the cylinder, creating more time for nitrogen to react with oxygen leading to higher $\mathrm{NO}_{\mathrm{x}}$ emissions [58]. It was observed that fuel blends number 1 and 18 showed the lowest and highest $\mathrm{NO}_{\mathrm{x}}$ emissions, respectively, which is in accordance with published literature [59].

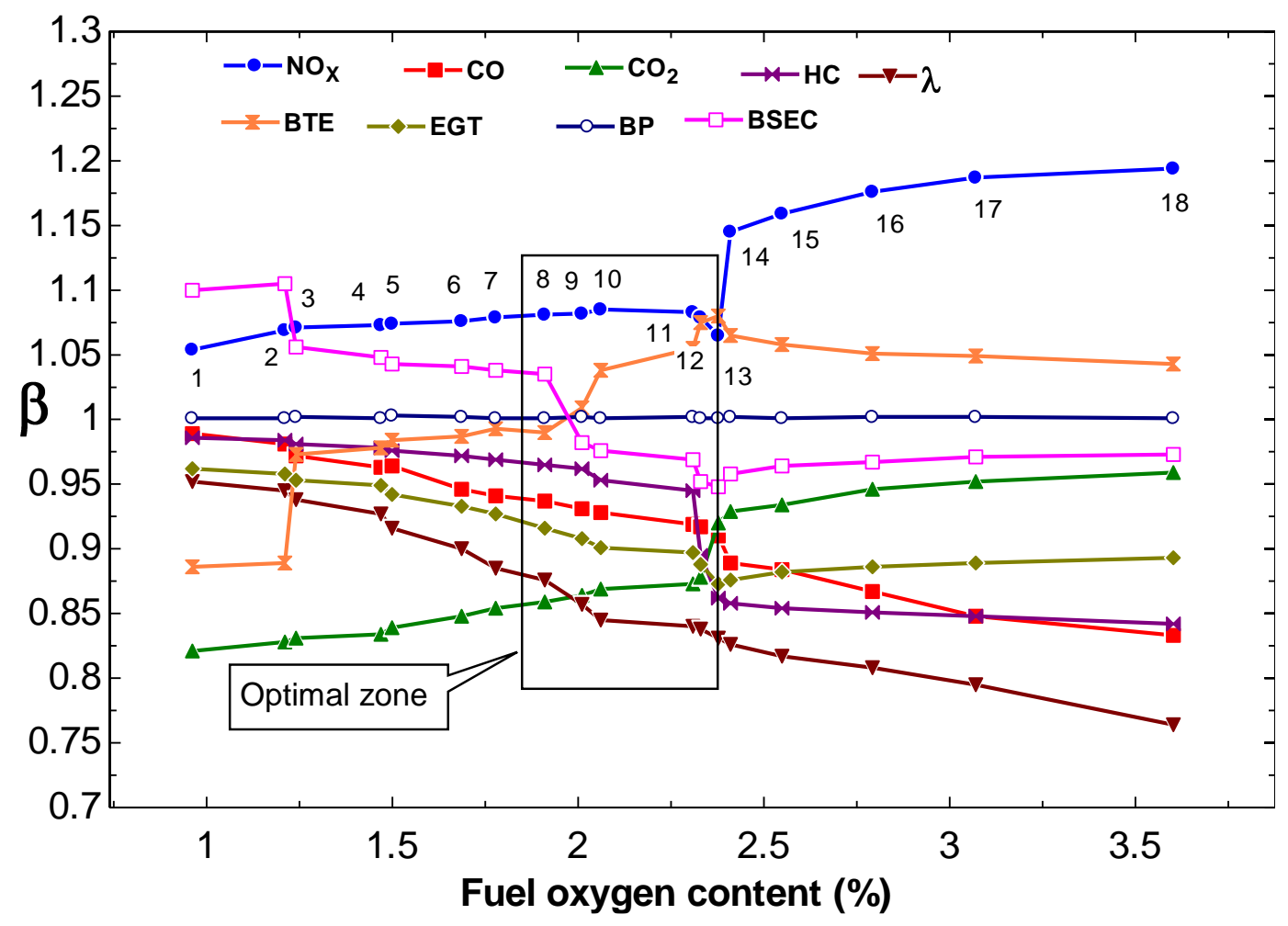

Figure 5. Combined effect of $\beta_{\text {emission parameters }}$ and $\beta_{\text {engine performance parameters with fuel }}$ oxygen content.

\section{Combined Effect of Engine Performance with Emissions}

From the engine performance analysis, it was evident that oxygen content between $1.8 \%$ $3.0 \%$ provided the best engine performance whereby the BSEC for fuel blends was in the minimum range while the BTE was in the maximum range. On the other hand, based on results from emission analysis, the $\mathrm{CO}, \mathrm{HC}$, and smoke opacity trends satisfied this region as these emissions continuously decreased with an increase in oxygen content, which may be attributed to a more complete combustion with presence of higher oxygen content. This agrees with published literature $[60,61]$. On the contrary, results of $\mathrm{NO}_{\mathrm{x}}$ and $\mathrm{CO}_{2}$ emissions suggested a region of interest from $0.71 \%$ (lowest) up to $2.37 \%$. Thus, considering both constraints, engine performance and emissions, the optimal zone of oxygen content for each fuel types were evaluated and are presented in Figure 5. The range of oxygen content in this optimal zone was found to be $1.80 \%-2.37 \%$. Fuel blends 
within this zone, i.e. fuel blends $8-13$, showed better engine performance and lower exhaust emissions. The best fuel blend in this range may be fuel blend number 13, composed of $2.37 \%$ oxygen, $84.88 \%$ carbon, and $12.56 \%$ hydrogen contents. Its chemical formula was evaluated to be $C_{19} H_{33.8} O_{0.4}$ with a molecular weight of $275.02 \mathrm{~kg} / \mathrm{kmol}$.

\section{CONCLUSIONS}

The present work aimed to study the effect of fuel oxygen content of SB-diesel blends on the performance and emission of a $\mathrm{CI}$ engine. From the analysis and wide range of results obtained, it can be concluded that the engine performed at its best when the oxygen content in the fuel blends laid between 1.8\%-3.0\%. Within this range of oxygen content, the BSEC for the fuel blends was found to be minimum whereas the BTE was found to be maximum for all the considered biodiesel blends. Furthermore, the BTE and BSEC of the biodiesel blends were found to be superior to those of diesel for oxygen content above $1.8 \%$. From the results of emission analysis at the best performing loading condition, the $\mathrm{CO}, \mathrm{HC}$, and smoke opacity trends were discovered to continuously decrease with increase in oxygen content in the fuel blends. All these emissions were found to be lower for all SB blends compared to diesel. On the contrary, the results of $\mathrm{NO}_{\mathrm{x}}$ and $\mathrm{CO}_{2}$ emissions suggested that the region of interest for oxygen content in the fuel blends laid in the range between $0.71 \%$ (lowest) to $2.37 \%$. Considering the importance of $\mathrm{NO}_{\mathrm{x}}$ and $\mathrm{CO}_{2}$ emissions, the suitable region in terms of oxygen content was found to be $0.71 \%-$ $2.37 \%$ for the selected fuel blends. Moreover, considering both engine performance and emissions, the optimal zone of oxygen content was found to be $1.80 \%-2.37 \%$. Fuel blends within this optimal zone, i.e. fuel blend 8-13 showed better engine performance and lower exhaust emissions. In addition, fuel blend number 13 may be regarded as the best fuel blend in this range owing to its superior engine performance and emission results compared to other fuel blends. Thus, it may be concluded that biodiesel blends having a fuel oxygen content in the range of $1.80 \%-2.37 \%$ can be successfully used as fuel in a diesel engine with at par engine performance, lower $\mathrm{CO}, \mathrm{HC}$, and smoke emissions, and acceptable $\mathrm{NO}_{x}$ and $\mathrm{CO}_{2}$ emissions. However, this range of oxygen content tends to limit the overall biofuel component in the fuel blend, i.e. up to $25 \%$ only, as shown in the present study. Hence, further research is much desirable to increase the overall biofuel component in the blended fuel beyond $25 \%$ while maintaining the fuel oxygen content in the $1.80 \%-2.37 \%$ range. Furthermore, research focus may be directed towards use of suitable additives to biodiesel blended fuel to reduce oxygen content to the suggested range.

\section{ACKNOWLEDGEMENTS}

The authors are extremely thankful to the Department of Mechanical Engineering, National Institute of Technology Silchar, Silchar, Assam for providing requisite laboratory facilities for carrying out biodiesel production, fuel characterization and the engine experiments for the present experimental investigation.

\section{REFERENCES}

[1] Demirbas A. Progress and recent trends in biofuels. Progress in Energy and Combustion Science. 2007;33:1-18. 
[2] Aldhaidhawi M, Chiriac R, Badescu V. Ignition delay, combustion and emission characteristics of Diesel engine fueled with rapeseed biodiesel-A literature review. Renewable and Sustainable Energy Reviews. 2017;73:178-86.

[3] Jiotode Y, Agarwal AK. Endoscopic combustion characterization of Jatropha biodiesel in a compression ignition engine. Energy. 2017;119:845-51.

[4] Yildiz M, Çeper BA. Estimation of equilibrium combustion products of dieselbiodiesel fuel blends using the developed solving process for $\mathrm{CnHm}$ and $\mathrm{C} \alpha \mathrm{H} \beta \mathrm{Oy}$ fuel types. International Journal of Automotive and Mechanical Engineering. 2017;14:4332-47.

[5] Saifuddin N, Refal H, Kumaran P. Performance and emission characteristics of micro gas turbine engine fuelled with bioethanol-diesel-biodiesel blends. International Journal of Automotive and Mechanical Engineering. 2017;14:403049.

[6] Shukri MR, Rahman MM, Ramasamy D, Kadirgama K. Artificial neural network optimization modeling on engine performance of diesel engine using biodiesel fuel. International Journal of Automotive and Mechanical Engineering. 2015;11:2332-47.

[7] Hasan MM, Rahman MM, Kadirgama K. A review on homogeneous charge compression ignition engine performance using biodiesel-diesel blend as a fuel. International Journal of Automotive and Mechanical Engineering. 2015;11:2199211.

[8] Misra R, Murthy M. Performance, emission and combustion evaluation of soapnut oil-diesel blends in a compression ignition engine. Fuel. 2011;90:2514-8.

[9] Chen Y-H, Chiang T-H, Chen J-H. An optimum biodiesel combination: Jatropha and soapnut oil biodiesel blends. Fuel. 2012;92:377-80.

[10] Chen Y-H, Chiang T-H, Chen J-H. Properties of soapnut (Sapindus mukorossi) oil biodiesel and its blends with diesel. Biomass and bioenergy. 2013;52:15-21.

[11] Chen Y-H, Tang T-C, Chiang T-H, Huang B-Y, Chang C-Y, Chiang P-C, et al. A complementary biodiesel blend from soapnut oil and free fatty acids. Energies. 2012;5:3137-48.

[12] Canakci M, Sanli H. Biodiesel production from various feedstocks and their effects on the fuel properties. Journal of industrial microbiology \& biotechnology. 2008;35:431-41.

[13] Mohd Noor CW, Mamat R, Najafi G, Mat Yasin MH, Ihsan CK, Noor MM. Prediction of marine diesel engine performance by using artificial neural network model. Journal of Mechanical Engineering and Sciences. 2016;10:1917-30.

[14] Kettner M, Dechent S, Hofmann M, Huber E, Arruga H, Mamat R, et al. Investigating the influence of water injection on the emissions of a diesel engine. Journal of Mechanical Engineering and Sciences. 2016;10:1863-81.

[15] Ibrahim F, Wan Mahmood WMF, Abdullah S, Abu Mansor MR. Numerical investigation of soot mass concentration in compression ignition diesel engine. Journal of Mechanical Engineering and Sciences. 2016;10:2275-87.

[16] Agarwal AK, Gupta T, Dixit N, Shukla PC. Assessment of toxic potential of primary and secondary particulates/aerosols from biodiesel vis-a-vis mineral diesel fuelled engine. Inhalation toxicology. 2013;25:325-32.

[17] Hasan M, Rahman M, Kadirgama K. A review on homogeneous charge compression ignition engine performance using biodiesel-diesel blend as a fuel. International Journal of Automotive and Mechanical Engineering. 2015;11:2199211. 
[18] Mofijur M, Rasul M, Hassan N. Effect of butanol additive on the performance and emission of Australian macadamia biodiesel fuel in a diesel engine. 2nd International Conference on Sustainable and Renewable Energy Engineering; 2017. p. 33-7.

[19] Datta A, Mandal BK. Engine performance, combustion and emission characteristics of a compression ignition engine operating on different biodieselalcohol blends. Energy. 2017;125:470-83.

[20] Babu AK, Devaradjane G. Vegetable oils and their derivatives as fuels for CI engines: an overview. SAE Technical Paper; 2003.

[21] Ribeiro NM, Pinto AC, Quintella CM, da Rocha GO, Teixeira LS, Guarieiro LL, et al. The role of additives for diesel and diesel blended (ethanol or biodiesel) fuels: a review. Energy \& Fuels. 2007;21:2433-45.

[22] Murugesan A, Umarani C, Subramanian R, Nedunchezhian N. Bio-diesel as an alternative fuel for diesel engines - a review. Renewable and Sustainable Energy Reviews. 2009;13:653-62.

[23] Mahmudul H, Hagos F, Mamat R, Adam AA, Ishak W, Alenezi R. Production, characterization and performance of biodiesel as an alternative fuel in diesel engines-A review. Renewable and Sustainable Energy Reviews. 2017;72:497509.

[24] Mofijur M, Atabani A, Masjuki Ha, Kalam M, Masum B. A study on the effects of promising edible and non-edible biodiesel feedstocks on engine performance and emissions production: a comparative evaluation. Renewable and Sustainable Energy Reviews. 2013;23:391-404.

[25] Amir K, Syamim M, Mustaffa N, Azwan S, Izzuddin Z, Manshoor B, et al. Experimental investigations on the use of preheated biodiesel as fuel in various load conditions of diesel engine. Australian Journal of Basic and Applied Sciences. 2014;8:423-30.

[26] Lahane S, Subramanian K. Impact of nozzle holes configuration on fuel spray, wall impingement and $\mathrm{NO} x$ emission of a diesel engine for biodiesel-diesel blend (B20). Applied Thermal Engineering. 2014;64:307-14.

[27] Hoque N, Mourshed M, Das BK. Performance and emission comparison of Karanja (pongamia pinnata), Pithraj (aphanamixis polystachya), Neem (azadira chtaindica) and Mahua (madhuca longofolia) seed oil as a potential feedstock for biodiesel production in Bangladesh. International Journal of Automotive and Mechanical Engineering. 2015;12:2967-82.

[28] Ghafoori M, Ghobadian B, Najafi G, Layeghi M, Rashidi A, Mamat R. Effect of nano-particles on the performance and emission of a diesel engine using biodieseldiesel blend. International Journal of Automotive and Mechanical Engineering. 2015;12:3097-108.

[29] Vashist D, Ahmad M. Statistical analysis of diesel engine performance for castor and jatropha biodiesel-blended fuel. International Journal of Automotive and Mechanical Engineering. 2014;10:2155-69.

[30] Chauhan BS, Kumar N, Cho HM. A study on the performance and emission of a diesel engine fueled with Jatropha biodiesel oil and its blends. Energy. 2012;37:616-22.

[31] Altaie MAH, Janius RB, Rashid U, Taufiq-Yap YH, Yunus R, Zakaria R, et al. Performance and exhaust emission characteristics of direct-injection diesel engine fueled with enriched biodiesel. Energy Conversion and Management. 2015;106:365-72. 
[32] Alptekin E. Emission, injection and combustion characteristics of biodiesel and oxygenated fuel blends in a common rail diesel engine. Energy. 2017;119:44-52.

[33] Gumus M, Kasifoglu S. Performance and emission evaluation of a compression ignition engine using a biodiesel (apricot seed kernel oil methyl ester) and its blends with diesel fuel. Biomass and bioenergy. 2010;34:134-9.

[34] Ramadhas A, Muraleedharan C, Jayaraj S. Performance and emission evaluation of a diesel engine fueled with methyl esters of rubber seed oil. Renewable Energy. 2005;30:1789-800.

[35] Usta N, Öztürk E, Can Ö, Conkur E, Nas S, Con A, et al. Combustion of biodiesel fuel produced from hazelnut soapstock/waste sunflower oil mixture in a diesel engine. Energy Conversion and Management. 2005;46:741-55.

[36] Ramadhas A, Jayaraj S, Muraleedharan C. Use of vegetable oils as IC engine fuels - a review. Renewable Energy. 2004;29:727-42.

[37] Kalam M, Husnawan M, Masjuki H. Exhaust emission and combustion evaluation of coconut oil-powered indirect injection diesel engine. Renewable Energy. 2003;28:2405-15.

[38] Nayak S, Mishra P. Emission from a dual fuel operated diesel engine fuelled with Calophyllum Inophyllum biodiesel and producer gas. International Journal of Automotive \& Mechanical Engineering. 2017;14:3954-69.

[39] Nayak C, Pattanaik B, Nayak S. Effect of preheated jatropha oil and jatropha oil methyl ester with producer gas on diesel engine performance. International Journal of Automotive and Mechanical Engineering. 2014;9:1709-22.

[40] Raheman H, Phadatare A. Diesel engine emissions and performance from blends of karanja methyl ester and diesel. Biomass and bioenergy. 2004;27:393-7.

[41] Bhaskar K, Sendilvelan S, Muthu V, Aravindraj S. Performance and emission characteristics of compression ignition engine using methyl ester blends of jatropha and fish oil. Journal of Mechanical Engineering and Scienes. 2016;10:1984-97.

[42] Sukjit E, Herreros J, Dearn K, García-Contreras R, Tsolakis A. The effect of the addition of individual methyl esters on the combustion and emissions of ethanol and butanol-diesel blends. Energy. 2012;42:364-74.

[43] Tan P-q, Hu Z-y, Lou D-m, Li Z-j. Exhaust emissions from a light-duty diesel engine with Jatropha biodiesel fuel. Energy. 2012;39:356-62.

[44] Xue J, Grift TE, Hansen AC. Effect of biodiesel on engine performances and emissions. Renewable and Sustainable Energy Reviews. 2011;15:1098-116.

[45] Misra R, Murthy M. Straight vegetable oils usage in a compression ignition engine-A review. Renewable and Sustainable Energy Reviews. 2010;14:300513.

[46] Karabektas M. The effects of turbocharger on the performance and exhaust emissions of a diesel engine fuelled with biodiesel. Renewable Energy. 2009;34:989-93.

[47] Lin C-Y, Lin H-A. Diesel engine performance and emission characteristics of biodiesel produced by the peroxidation process. Fuel. 2006;85:298-305.

[48] Azad AK, Rasul M, Giannangelo B, Islam R. Comparative study of diesel engine performance and emission with soybean and waste oil biodiesel fuels. International Journal of Automotive and Mechanical Engineering. 2015;12:2866.

[49] Dubey P, Gupta R. Study of the performance and emission characteristics for a dual fuel powered single cylinder diesel engine. International Journal of Automotive and Mechanical Engineering. 2016;13:3373-88. 
[50] Sureshkumar K, Velraj R, Ganesan R. Performance and exhaust emission characteristics of a CI engine fueled with Pongamia pinnata methyl ester (PPME) and its blends with diesel. Renewable Energy. 2008;33:2294-302.

[51] Chauhan BS, Kumar N, Cho HM, Lim HC. A study on the performance and emission of a diesel engine fueled with Karanja biodiesel and its blends. Energy. 2013;56:1-7.

[52] Jaichandar S, Annamalai K. Jatropha oil methyl ester as diesel engine fuel-an experimental investigation. International Journal of Automotive and Mechanical Engineering. 2016;13:3248-61.

[53] Musculus MP, Lachaux T, Pickett LM, Idicheria CA. End-of-injection overmixing and unburned hydrocarbon emissions in low-temperature-combustion diesel engines. SAE Technical Paper; 2007.

[54] Monyem A, Van Gerpen JH. The effect of biodiesel oxidation on engine performance and emissions. Biomass and bioenergy. 2001;20:317-25.

[55] Yu R, Wong V, Shahed S. Sources of Hydrocarbon emissions from direct injection diesel engines. SAE Technical Paper; 1980.

[56] Varatharajan K, Cheralathan M, Velraj R. Mitigation of NOx emissions from a jatropha biodiesel fuelled DI diesel engine using antioxidant additives. Fuel. 2011;90:2721-5.

[57] Sun J, Caton JA, Jacobs TJ. Oxides of nitrogen emissions from biodiesel-fuelled diesel engines. Progress in Energy and Combustion Science. 2010;36:677-95.

[58] Hoque N, Mourshed M, Das B. Performance and emission comparison of Karanja (pongamia pinnata), Pithraj (aphanamixis polystachya), Neem (azadira chtaindica) and Mahua (madhuca longofolia) seed oil as a potential feedstock for biodiesel production in Bangladesh. International Journal of Automotive and Mechanical Engineering. 2015;12:2967.

[59] Labeckas G, Slavinskas S. The effect of rapeseed oil methyl ester on direct injection diesel engine performance and exhaust emissions. Energy Conversion and Management. 2006;47:1954-67.

[60] Sendzikiene E, Makareviciene V, Janulis P. Influence of fuel oxygen content on diesel engine exhaust emissions. Renewable Energy. 2006;31:2505-12.

[61] Choi C-Y, Reitz RD. An experimental study on the effects of oxygenated fuel blends and multiple injection strategies on DI diesel engine emissions. Fuel. 1999;78:1303-17. 